\title{
Development of a phyto-stabilization strategy based on the optimization of endogenous vegetal species development on a former arsenic-bearing mine waste
}

\author{
H. Thouin ${ }^{1}$, M.P. Norini ${ }^{1}$, P. Gautret ${ }^{1}$, M. Motelica ${ }^{1}$, F. Battaglia-Brunet ${ }^{2}$, \\ L. Le Forestier ${ }^{1}$, L. De Lary De Latour ${ }^{2} \&$ M. Beaulieu ${ }^{2}$ \\ ${ }^{1}$ BRGM, ISTO, Orléans, France \\ ${ }^{2} B R G M$, Orléans, France
}

\begin{abstract}
In order to promote the development of a vegetal cover on a dump of mining residues, endogenous plants that started to colonize the waste material were collected and identified. The strategy of remediation included the selection of amendments that could optimally promote plant growth and decrease the mobility and bio-availability of the main toxic elements present in the residue, i.e., arsenic, lead and barium.
\end{abstract}

\section{INTRODUCTION}

Mine residues sometimes present risks associated with the dispersion of solid particles containing toxic elements, such as arsenic, and can also induce a pollution of groundwater and surface water through leaching. Phyto-stabilization strategies have been proposed as promising remediation options in order to decrease the risk of transfer of arsenic and heavy metals from the residues to the surrounding environment and to the biotope (Hattab et al., 2015, Moreno-Jimenez et al., 2017). However, the harmonious development of a vegetal cover that will efficiently stabilize the toxic elements for a long time is difficult to control: scientific and technical obstacles linked to the specific needs of the endogenous plants in terms of soil texture and nutrient needs must be linked to the minimization of toxic elements mobility. We present here the first steps of the development of the phytostabilization strategy for an arsenic-bearing mining waste.

\section{METHODS}

\subsection{Site description and residue sampling}

The materials were sampled on a former silver and lead mining site, exploited from the antiquity but with the highest activity in the second half of the XIXth century (Sabourault et al., 2016). This mine is located in medium mountain (altitude $750 \mathrm{~m}$ ). Mine residues $\left(3 \mathrm{~m}^{3}\right)$ were recovered from the $0-60 \mathrm{~cm}$ level of a mine waste dump, using a power shovel. Residues were taken in seven discrete zones in a $25 \mathrm{~m}^{2}$ area. Measurements of arsenic and metals concentrations were performed on site using an X-ray fluorescence apparatus Niton Xlt999. The material was coarsely mixed with the shovel and transported to the laboratory for multi-scale experiments.

\subsection{Sampling of vegetal specimens}

Plants were sampled with their balled roots, in several types of substrates: (1) on the margin of the mining residues, where pedogenesis supported by the natural supply of organic litter already generated a soil-like structure; (2) directly in the sand-like yellow residues, and (3) in the intermediary substrate, presenting finer and darker phases than the sandy waste. The plants were immediately installed in pots, brought to the laboratory and maintained out-door in big tanks filled with mine residues, pure or mixed with organic litter from the site. The organic litter, composed of leaves from trees (oak and birch mainly) was sampled on the margin of the mining dump.

\section{RESULTS AND DISCUSSION}

\subsection{Concentrations in arsenic and metals}

The on-site quantification of arsenic and metals concentrations in the residues showed high concentrations in lead (from 12 to $38 \mathrm{~g} \mathrm{~kg}^{-1}$, average value $17 \mathrm{~g} \mathrm{~kg}^{-1}$ ), arsenic (from 0.5 to $2.2 \mathrm{~g} \mathrm{~kg}^{-1}$, average value $1.6 \mathrm{~g} \mathrm{~kg}^{-1}$ ) and zinc (from 0.13 to $2.7 \mathrm{~g} \mathrm{~kg}^{-1}$, average value $0.47 \mathrm{~g} \mathrm{~kg}^{-1}$ ).

\subsection{Sampling and identification of endogenous vegetal species}

The endogenous plants collected on site, resistant to arsenic and lead, were identified as belonging to 

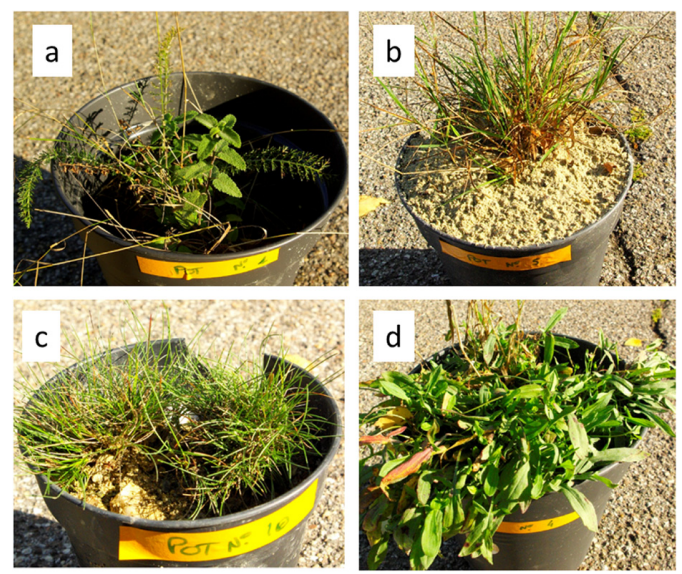

Figure 1. Endogenous plants (a) Teucrium scorodonia, Achillea millefolium growing on a soil-like substratum at the margin of the dump, (b) Agrostis and (c) Festuca) directly in the sandy waste, and (d) Rumex) in an intermediary substratum.

diverse genera that seemed to colonize three different types of substrates on the dumping areas (Fig. 1):

- The margin of the residue, where pedogenesis supported by the natural supply of organic litter already generated a soil-like structure was colonized by Teucrium scorodonia L., Achillea millefolium L.

- The mine residue, i.e. the sand-like yellow residues, was colonized by Agrostis sp. and Festuca sp., two genera previously found on metals-polluted sites (Ernst, 2006).

- The intermediary substrate, presenting finer and darker phases than the sandy waste, supported the growth of Lotus corniculatus, Hypochaeris radicata L., Polygonum aviculare L. Persicaria sp., Scrofularia sp., Linaria repens, Silene vulgaris (Moench) Garcke, Cerastium sp.

Rumex acetosella $\mathrm{L}$. was found on different substrates. This species is otherwise known to be able As accumulation in this tissue contrary to excluder species which restricted As uptake (Otones et al., 2011).

These vegetal specimens are thus adapted to both toxic elements (arsenic, lead), and to the site climate, with negative winter temperatures.

\subsection{Stabilization of arsenic in the mine residue}

The next steps of the research program will tend to optimize the stabilization of arsenic and other toxic elements (lead, zinc and barium) combining the stimulation of colonization by vegetal species and the geochemical and biogeochemical stabilization of pollutants. Different amendments (iron- and organic matter- bearing materials) will be tested, alone and in combination. The mobility of arsenic and other toxic elements in presence of plants will be assessed from the unsaturated to the water saturated zone in mesocosm experiments. The evolution of microbial communities, including As-transforming microbes, will be monitored along with the evolution of vegetal cover and water/soil geochemistry.

\section{CONCLUSIONS}

A range of vegetal species are specifically adapted to the presence of arsenic and to the physico-chemical conditions of each specific mine site, including climate. Here, a methodology has been developed in order to optimize the phyto-stabilization process using a multi-scale experimental program closely linking site, laboratory and mesocosm experiments.

\section{ACKNOWLEDGEMENTS}

This research work is performed in the frame of Phytoselect project funded by the Region Centre Val de Loire, contract $\mathrm{N}^{\circ} 2016-00108485$, and by the Labex Voltaire (ANR-10-LABX-100-01). We gratefully acknowledge the financial support provided to the PIVOTS project by the Région Centre - Val de Loire (ARD 2020 program and CPER 2015-2020) and the French Ministry of Higher Education and Research (CPER 2015-2020 and public service subsidy to BRGM). This operation is co-funded by European Union. Europe is committed to the Center-Val de Loire region with the European Regional Development Fund.

\section{REFERENCES}

Ernst, W.H.O. 2006. Evolution of metal tolerance in higher plants. For. Snow \& Landsc. Res. 80(3): 251-274

Hattab, N., Motelica-Heino, M., Faure, O. \& Bouchardon, J.-L. 2015. Effect of fresh and mature organic amendments on the phytoremediation of technosols contaminated with high concentrations of trace elements. J. Environ. Manag. 159: $37-47$.

Moreno-Jiménez, E., Sepúlveda, R., Esteban, E. \& Beesley, L. 2017. Efficiency of organic and mineral based amendments to reduce metal [loid] mobility and uptake (Lolium perenne) from a pyrite-waste contaminated soil. J. Geochem. Explor. 174: 46-52.

Otones, V., Álvarez-Ayuso, E., García-Sánchez, A., Santa Regina, I. \& Murciego, A. 2011. Mobility and phytoavailability of arsenic in an abandoned mining area. Geoderma 166(1): 153-161.

Sabourault, P., Niemiec, N., Pidod, A. \& Girardeau, I. 2016. Le district minier de plomb-argentifère de Pontgibaud (France): vers une résilience des anciens dépôts de résidus de traitement du minerai. GESRIM, 2nd International Congress on the Management of Mining Wastes and Post-Mining. 